\title{
Renewing Party Scholarship: Lessons from Abroad
}

\author{
Kay Lawson, San Francisco State University
}

In no domain of political science scholarship have we paid a higher price for our discipline's insistence on separating "American" and "Comparative" studies than in the domain of parties, and never has the error of our ways been more striking than now. Although we have readily consented to weave such terms as "globalism," "interdependence," and even "new world order" casually into our discourse, most of us have not seriously imagined that the momentous developments these terms summon to mind have serious meaning for the way we study our own political parties - nor have we made significant changes in the way we study the parties of others. ${ }^{1}$

The need for party scholarship renewal is not owing only to massive change in world politics. Recent events make this need more obvious and more compelling, but have not invented the problems we share. We made these problems for ourselves, long ago. We made them by accepting two norms, one apparently commendable, the second apparently unavoidable: realism and parochialism.

Our study of parties has been guided by our desire to be realistic. Parties, we have correctly remarked, are organizations formed for the pursuit of power which seek to gain that power by placing some of their own members in public office, via elections. ${ }^{2}$ If we want to understand how parties work, and why they work as they do, we must keep in mind that the goal is power, which means, in turn, understanding how power is most efficiently pursued today (see e.g., Schlesinger 1991, 1985). Political powerseekers now have two paramount needs: enough money to buy the usage of the new communications technology and enough skill to use that technology well. The two needs are conveniently interrelated: skillful use of the technology produces not only popular support but also more money. More money buys not only more access to communications technology but also the time of those skilled in its use. ${ }^{3}$

Realism tells us that all other needs are subordinate. Those who lack money and skill for the use of computer polling and targeting, direct mail, and radio and television presentations are crippled in their pursuit of power. ${ }^{4}$

KAY LAWSON is Professor of Political Science at San Francisco State University.

The American Review of Politics, Vol. 14, Winter, 1993: 577-592

(C)1993 The American Review of Politics 
Parties seek power via candidates who win. Focusing on other topics may, we fear, cause us to forget this one, tough truth. It may be of normative interest to study the extent of internal party democracy, but in practice internal democracy is likely to impede the ability of parties to adopt programs or recruit candidatures which can be successfully communicated; the realistic questions regarding internal organization are those that focus on what kind of organization provides the best support for effective communication of the party's message. Similarly, giving scholarly attention to issues and to the personal attributes of a party's candidates is realistic only when couched in terms of the party's power-seeking needs: candidates who pursue unpopular issues and/or have unattractive personal characteristics are likely to lose, however useful their ideas and traits might prove once they held office. The key variable for the realistic study of power-seeking parties is communicative effectiveness. We study the acquisition and use parties make of money, skill, organization, issues and candidate personalities in terms of how well they use these assets in the quest for power.

All this is simply "true." It is no use pretending otherwise, we have told ourselves, and we are right, so long as what we want to understand is the dynamics of power-seeking via parties. There is, however, much more to study about parties than how well they succeed in helping candidates win elections. Comparing our own parties more frequently with the parties of other nations would remind us of these other variables, and why they are important. As it is, our realistic study of our own two major parties has produced solid scholarship, and led to important understandings. But it is scholarship behind American walls. We rarely allow either foreign theory or foreign fact admission. If we think about "others" at all, we tend to do so in terms of the advisability and feasibility of exporting American models to them. We rarely if ever imagine we might have something to learn, as scholars, and that our parties might have something to learn, as political organizations, by examining the parties of other nations.

In sum, it is realism combined with parochialism which has crippled our study of our own parties, and tainted and truncated our study of the parties of others.

This is not to say that parties in other nations do not have the same concerns. The communications revolution is international in scope, and parties everywhere must gain access to its instruments. ${ }^{5}$ But when we turn our attention abroad, we are almost immediately reminded of two very important phenomena, interrelated, multi-faceted and far more relevant to our understanding of our own parties than our customary neglect of them would suggest: (1) different conditions make it possible and necessary for parties to meet the new communication needs differently in different polities, and 
(2) there are important variables to study when examining parties besides the question of how well they pursue electoral success. In this chapter, I will pursue these two points in turn, citing examples from various systems as space permits.

\section{How Context Shapes Parties' Ability to Communicate}

Even if our concern were only to know how parties pursue power, and our major focus thus the factors that shape their ability to communicate their message in today's world, comparative study of the conditions under which parties in different nations must labor to accomplish the same end would sharpen our understanding of the impact of contextual factors on American parties. We would be more likely to remember that many of these factors are subject to change, not only from place to place, but over time, that the American context we take so for granted in our study of our own parties is itself in flux, and that these contextual changes have profound effect on the ability of parties to meet the communication challenges of the 1990s. Here I will simply look briefly at five of the multitude of contextual features that can influence the capacity of parties to get the money and skills they need in order to make effective use of modern campaign techniques: constitutions, party-related laws, relevant societal norms, non-party competition, and degree of system stability.

We are well aware of the impact of constitutions on party systems in general, but what kind of constitutional system a nation has also has a specific effect on what parties need in order to campaign effectively. Consider two examples. In parliamentary systems in unitary states, in which power is strongly concentrated in the dominant or majority party and exercised via the prime ministership, parties are able to concentrate most of their communication resources on the task of winning as many legislative seats as possible, without reserving a major portion of their resources for the contest for the position of chief executive. Of course parties in such systems normally find it desirable to find and expend some of their resources on the campaigns of candidates for local or intermediate levels of office: even though local powers may always be repossessed by the national government in a unitary system, campaigning for and winning local elections is itself an important way to win credence for the party's message nationally. But even when considerable stress is laid on local elections, in a classical unitary parliamentary system power, and therefore parties' expenditure of money and expertise on communication, goes to a limited number of receivers. This not only simplifies fund-raising and spending; it also means that in such a system key power-holders depend on their parties, and are loyal to them. 
Maverick candidacies occasionally take place, but by and large parties in parliamentary systems are able to develop national programs of considerable specificity, even when some of their candidates are unenthusiastic about some of the stands they take, and, if they win power and their programs are feasible, to carry them out. ${ }^{6}$

On the other hand, in presidential systems in federal states, in which power is subdivided between national and local levels as well as between the national branches of government of which two are open to partisan contest, the distribution of party communication resources poses far more difficult questions. Not only must the parties seek to strengthen the campaigns of candidates for office in all the states or provinces, in the legislature, and in the presidency, because all these elective offices possess separate and important powers, but they must often do so quite differently, from office to office and from place to place. With the fragmentation of power comes the fragmentation of electorate and of party image: what is desired or tolerable in the party's program in one place, at one level of government, may or may not be at another. Such fragmentation contributes in turn to the diminished importance of party and party program. As the party cannot risk presenting a consistent detailed program everywhere, and yet must achieve a national identity in order to have a hope of attracting a candidate capable of winning the presidency, it is forced into presenting an image of itself that is vague and centrist, while allowing the candidates who use its name to give that program a multitude of more specific interpretations - or none at all. The result is much less emphasis than in parliamentary systems on detailed party program content, and much more on personal characteristics of candidates, especially the candidate for the presidency.

Constitutions are not impossible to change, but the task is certainly not an easy one, particularly in systems where the document in place receives as much uncritical adulation as does our own. But statutory law is easier to change, and party-relevant law is a second contextual factor influencing the ability of parties to communicate effectively. Laws regulate how parties and candidates gather funds, whether or not they will be helped by public financing of their campaigns, whether or not they will have free access to the media, and whether or not they will be allowed to use paid advertising. Less directly, statutory law influences parties' ability to communicate to voters by determining the electoral system to be used: significantly different skills are required to communicate effectively under systems of proportional representation (which encourages party list-making, and thereby greater emphasis on party program and image) and the single-member district system (which encourages personalization of candidatures and reduces the role of parties). ${ }^{7}$ 
The French system of run-off elections in single-member districts adds another complication, often forcing ideologically close parties to contend bitterly with each other throughout most of the election season and then work together amicably in second-ballot alliances. The abruptness of the transformation reminds us of what happens when a candidate for major party nomination in the U.S. becomes the running mate of his or her former competitor-but places greater strain on the parties' efforts to maintain communicative credibility, because in France the first stage of the battle will have taken place between party-endorsed candidates, and thus between parties (not individual contenders for a party's nomination, in which case the party must appear to remain quietly neutral).

Also important for communicative success are the laws which determine parties' right of access to the ballot: when new parties must spend large sums of money to gather the signatures necessary to qualify, they will obviously have less to spend on the services of experts for the actual campaign. Laws may also regulate the procedures by which candidates may be selected - as noted, American primary elections, non-partisan contests for partisan labels, force party leaders to a pretense of neutrality, whereas party factions are freer to develop and struggle openly for intra-party caucus nominations - and both of these are in turn very different from systems which allow party leaders to exercise full and secret control over candidate selection without regulation or interference by the state, the public, or rank and file members of the party. ${ }^{8}$

The kind of campaign tactics that may or may not be used is also sometimes subject to legal regulation, as in the Japanese proviso against door to door campaigning. The United States is unique in having a large number of municipalities in which parties are denied the right to campaign for local office altogether, a proscription which certainly reduces the demands on parties for the expenditure of money and skill.

Societal norms are a third factor shaping parties' abilities to communicate effectively. French politicians' extramarital affairs are their own business, but many of the French find simplistic political advertising (still not permitted on television) unacceptably crass and deeply offensive. Similarly, evidence of a candidate's religious conviction and practice is an essential component of the campaign message in some nations, but considered utterly irrelevant or dangerously divisive in others. Other societal norms are more directly political, such as the level of approval - or disdain-normally accorded politicians or the polity's standards of what constitutes political corruption. Not every citizenry has the same standards regarding an elected official's use of the perquisites of office, the receipt of gifts from supporters, the hiring of friends and relations to government posts, and the use of inside 
information to achieve personal gain. In post-independence Nigera, novelist Chinua Achebe suggested the norm was "do not take so much that the owners notice" (the "owners" in this case being the people); however, what is noticed and deemed excessive may vary over time, as recent 'hegemonic party'-bashing elections in Italy and Japan have shown. In our own country, few Americans would now find William Plunkitt's $(1963,3)$ notion of "honest graft" other than oxymoronic, yet our tolerance of graft pure and simple seems to have grown exponentially: compare the ready outrage of public response to earlier mini-scandals (the Teapot Dome, the vicuna coat of the Eisenhower years) with the amount of time it took for the public to condemn the tactics of the Watergate coverup or with its forgetfulness regarding Koreagate, Irangate, the Keating Five, etc. Looking at such questions comparatively is more than amusing arm-chair traveling; it is a good way to explore the conditions under which norms develop and change, including the efforts parties themselves make to bring about changing standards of morality, particularly political morality.

A contextual factor influencing communicative effectiveness which we have not neglected is non-party competition. The increasing importance of single-interest groups and of the Political Action Committees associated both with them and with broader-based pressure groups has forced us to consider at length the way organizations other than parties have made it ever more difficult for parties to take and control power. However, much remains to be learned by considering more closely the wide range-both in issue content and in strength of appeal — of alternative forms of organization in other systems and the different means parties in those systems use to try to absorb or deflect the competitive messages these groups convey. Might we be able to deepen our understanding of our own parties' lukewarm-to-hostile response to the peace movement, whenever it has had occasion to surface, by considering how nuclear freeze advocates gained such a grip on the British Labour Party for so long (Kavanagh 1990, 299-300), while their counterparts have had so little impact on the programs of French parties? Might we not gain a better understanding of why and how women have found stronger roles in American parties, even as the sound of the antifeminist backlash continues to whistle in the American press, if we examine that phenomenon in contrast to the failure of women to achieve greater political parity in most other nations? We cannot fully understand why our parties handle the challenge of non-party competition as they do if we never look at the relationship between parties and groups in other lands.

Fifth and finally, the degree of political stability existent in a system clearly influences parties' abilities to communicate effectively. Rising crime and the inability to eliminate egregious social ills, not to mention sporadic 
outbursts of anti-system cult behavior and urban rioting have made us less confident of our own system's stability. We pay considerable attention to our parties' efforts to shift their messages to accommodate public dismay over these developments, at least in their rhetoric. But if we made better use of the extensive literature in comparative studies of the causes and effects of system instability we would be more alert to the possible relationship between malfunctioning systems and party decline, a relationship our most ardent proponents of party renewal have scarcely hinted may exist. ${ }^{9}$

In sum, even if all we care about is understanding what makes for power-winning communication by our own parties, comparative study of how constitutions, laws, societal norms, competitive non-party organizations, and the stability of systems shape parties' capacity in this regard - and how these factors change over time-can force us to pose new and interesting questions and lead us to important new insights. But there are other reasons for considering other nations' parties more often in our study of our own.

\section{Ex-Communication: How Parties Matter Other Than as Communicators}

What parties care about is winning elections. But why must we, scholars of party, confine ourselves to what parties care about when studying their organizations? In this regard, our "realistic" insistence on allowing the parties themselves to limit the scope of our inquiry is quite unreal. We do not study Congress solely by asking what Congress men and women wish to accomplish; we study it as an institution with important responsibilities, powers, and deficiencies in the political system. The same is true of the presidency, the courts, the public administration, local governments, and even private interest groups. Furthermore, when we do turn to the study of foreign parties, we almost always examine them in terms of their role in the systems in which they exist. When we consider that role, we roam freely across a range of important normative questions, without apparent embarrassment. It is perfectly all right, it seems, to ask of foreign parties how well they represent the range of opinions within the society, whether they are open or closed organizations, whether their leaders are honest or corrupt, whether they are moving their nations toward greater or lesser democracy, toward or away from a market economy - and what's more, to make quite unambiguously clear what we believe the "right" answer would be. It is only of our own parties that we dare not ask such questions, only in our own country that such questions are greeted as smacking of naive idealism and a shameful absence of objectivity. 


\section{4 | Kay Lawson}

If we were to take the same approach to our own parties that we take to parties elsewhere, and give as much attention to the impact of parties on our political system as we do to their role as power-seeking agencies, our research agenda would be considerably expanded. As our and others' comparative studies suggest, political parties have both positive and negative effects upon political systems. Among the positive we may list: articulating and aggregating interests, providing peaceful outlets for dissent, optimizing choice, facilitating intra-system cohesiveness of purpose, and maximizing regime legitimacy. On the other hand, parties have also been said to contribute to political fragmentation and the consequent immobilism of the policy-making process, to public contempt for politicians and all matters political, to the concentration of power and its perquisites in the hands of a narrow elite, to excessive participation by mass populations with an unrealistic sense of entitlement, and even to the overthrow of constitutional government.

Our examination of our own parties in terms of their impact on our political system has focused for the most part on only two of the above possibilities: optimizing choice and facilitating intra-system cohesiveness of purpose. With regard to how parties optimize choice in democratic systems, we have made numerous studies of the degree of party competitiveness. However, such studies are almost always focused on the extent of competitiveness between the two major parties. We take our two-party system so deeply (and so parochially) for granted that we normally ignore altogether how severely choice is limited by the multitude of restrictions inhibiting the development of minor parties. At the present time, over half a million signatures are required to get a new party's presidential candidate on the ballot of all 50 states, and the process of getting that number of signatures is fraught with difficulty: the courts have sustained the states' rights to prohibit those who voted in either of the major party primaries from signing, to require voters to furnish their registration numbers or their precinct numbers when signing, to require signers to declare that they will vote for the party whose petition they are signing or that they are members of that party, to charge the party as much as ten cents per signature to cover the costs of their validation, and to continue requiring a new party to petition election after election if it does not poll at least 20 percent of the votes cast in state government elections (Conlan 1986; Winger 1986). Might we not be quite righteously indignant were we to discover such restrictions imposed on the formation of new parties in newly democratizing nations? (And is it not more than a little naive to continue to ascribe the fact that we have only two major parties to the single member district electoral system [which has been shown not to eliminate multipartyism in other nations] or, worse, to the 
prevalence of a high degree of consensus in our all too visibly divided nation?)

We have also taken considerable interest in the capacity of our parties to facilitate intra-system cohesiveness of purpose. Elmer E. Schattschneider (1942) taught us that parties were essential to make a democratic government work, particularly within a system in which power is as divided as in our own. According to this perspective, parties are the only organizations that can offer reasonably consistent guidance to the users of power on all levels and in all branches of government; this ability can in turn give greater consistency to the activities of governments. Our investigations into the lack of incentives for maintaining party discipline, into the low levels of party cohesion within Congress, and into the difficulties of policy formulation when Congress and the Presidency are under the control of different parties, have given us a significant body of study relevant to this question. We may fail, as we almost always do, to note the logical contradictions between deploring low levels of party discipline and boasting of a strong tradition of bipartisanship in the making of foreign policy, but at least there is always an implicit comparative element in our studies of party cohesion: we know we are different and we know some of the reasons why.

However, even here there are problems. Our analyses of the essential first stage in the development of party discipline - the formation of a party program to which candidates and elected representatives might be asked to adhere-are seriously lacking in comparative perspective. While we do monitor the way programs are put together, taking note of interesting changes such as the greater influence of single interest groups, we do so like amnesiac archivists stranded on a desert isle, utterly forgetful of how things are being done otherwise in other climes. How is it that parties abroad produce and distribute programmatic statements that are so much more detailed than our own? Although we might well decide that such specificity in issue formulation would be politically impossible here, ought we not at least endeavor to place the paucity of substantive or distinctive content in American party platforms within that broader comparative context?

But we have not merely omitted important aspects of the two systemrelevant factors of optimizing choice and facilitating cohesiveness; we have omitted other aspects of how our parties influence our system almost entirely. Consider, for example, how we treat the important problem of nonvoting. It is at least an hypothesis worth investigating to suggest that a rate of abstention in elections as high as our own is a clear sign a nation's parties are not meeting the important linkage needs of articulating and aggregating interests, and providing peaceful outlets for dissent. But when we study our own high rates of abstention, we tend to ignore the role of political 
organizations, including parties, almost entirely, focusing instead on individuals. This omission is a particularly striking example of how we close important questions out of our study of parties, and merits more extended comment.

In the first place, we do not speak of abstention, which conjures up the notion of a thoughtful voluntary act, but rather of "turnout" by "voters." Those who do not vote in a particular election are not conceptualized, as they are, for example, in France, as abstaining electors; they are conceived as occupying an entirely passive role: "non-voters." The parties have not failed the citizens by providing unacceptable choices; the citizens have failed to accomplish a duty that should be done no matter how distasteful the conditions.

Having thus, with one fell semantic swoop, narrowed the scope and contorted the meaning of our studies, we are free to examine the correlations between personal characteristics and voting, and in doing so we rediscover (at least bi-annually) that voters are better educated, better informed, richer, and surer of their own efficacy than non-voters. These findings, combined with our discovery that normally non-voters have roughly the same opinions as voters about the issues that have been politicized and about the candidates who have been nominated, are very reassuring. For many, that is enough to lay to rest any whispering qualms regarding linkage: "non-voters" not only get what they deserve; they get what they want.

Of course not everyone is so easily satisfied. However, those of us who bear in mind Schattschneider's warning that our high rates of abstention may be dangerous (the "soft underbelly" of the American political system, he suggested) are seldom prompted to investigate the role of our party system in producing this result. We turn instead to such factors as the frequency of our elections or the difficulties of registration, jumping from the individual to system-wide variables, ignoring the possible role of intermediary organizations. When pressed, we may acknowledge that even when we add in such factors we are able to account for only a fraction of the variance between those who vote and those who do not and, further, that correlation is not the same as explanation. However, such admissions somehow never prompt us to direct our studies to the hypothesis that begs inquiry: potential voters are more likely to abstain the more they view the programs of the competing parties as irrelevant to their own interests and the candidates of those parties as unlikely to address those interests effectively.

This is not to suggest that we make no mention at all of parties in considering turnout. We do, for example, often ask respondents to state their party identification - do you consider yourself a strong Democrat, weak Democrat, independent, weak Republican or strong Republican - and then 
ask the voters among them which party's candidates they voted for. This permits us to make interesting comments regarding the relationship between party identification, turnout, and voter loyalty, but of course says nothing at all about any possible relationship between low turnout and party disaffection.

We ask no questions that bear directly on that possibility. We do not, for example, ask respondents to state their interests and their perception of the readiness of either major party to hear and respond to them-the closest we come is to ask how much the individual believes "political parties" (i.e., the two major parties in combination) work for the benefit of "persons like yourself." We do not ask whether or not new parties should be added to our system, and if so, what characteristics they should have. Nor do we ask questions regarding direct experiences members of the general population may have had in attempting to take an active part in existing organizations of our major parties - such questions are reserved for party activists, which means, of course, that the answers are highly unlikely to tell us anything about abstention (activists vote), including the possible relationship between one's perception of parties and a decision not to vote.

Of course studying abstention is not the only way to study the parties' effectiveness as agencies of interest articulation and aggregation. We could study the parties directly, observing the process at first hand. However, unlike the students of parties in other lands, we seem to have lost all faith in our own ability to make intelligent observations about how parties carry out the function of interest articulation and aggregation by going to see. We would rather rely on the statistical analysis of vast numbers of identically delimited information bits, gained by sending closed-ended and easily codable questionnaires to party activists and leaders. We know full well that their answers are likely to be tainted by loyalty to the organization, the desire to make a good impression, or a mixture of both, and we may suspect that careful professional analysis of open-ended interviews and the content of party meetings over a significant period of time, although time-consuming and certainly subject to the researcher's own bias, has the potential to tell us far more about a party's commitment to interest articulation and aggregation than can any summary of individual responses to closed questions impersonally posed. But that is not the way we work, and we remain for the most part blissfully ignorant of the results achieved by these still timehonored methods in other lands. ${ }^{10}$

Our investigation of the more positive ways parties may shape the systems in which they function is thus severely limited. However, when we turn to the question of the way parties may have a negative effect, we find that the topic occupies even less space on our research agenda. Do our 
parties help to concentrate power and its perquisites in the hands of a narrow elite (and if so, how)? Has our legislated avoidance of multiparty politics made our policy-making process any more efficient than those of more politically fragmented polities? What role have our parties played in increasing the dislike Americans have for politicians and all matters political? Have our parties been excessively open to interest group blandishments and funding, imposing unreasonable expectations of entitlement on an overburdened and overindebted political system? Have they served to subvert (rather than to overthrow) the functioning of our constitutional system?

Although in no case can we be sure the answer would be an unambiguous yes, each of these questions contains an hypothesis sufficiently plausible to merit study. With regard to the first, examination of studies of the Japanese and Italian ruling parties only recently removed from power could suggest to us ways to study the uses made of parties for maintaining elite control (and studying recent developments in those two nations, particularly Japan, could make us careful about assuming that when parties fail, so do the elites who have used them to maintain control). ${ }^{11}$

Similarly, developing indices for making a detailed comparison of the impact of parties on policy-making efficiency in our own and several multiparty systems should not be beyond our capabilities. And there are several studies already existent indicating the role played by parties in raising public contempt for political life, but the focus of such works is seldom directly on the parties: we need do little more than give such works more frequent acknowledgement in our own. ${ }^{12}$

It is also true that we already have most of the data we need for the fourth question, regarding whether-and if so, how-the relationship between interest groups and parties overloads our system. We already know how dependent our elected representatives have become on interest group funding, we already know how the parties have seized new opportunities to funnel that funding to their candidates, and we certainly already know that our system is overloaded and overindebted. What we need is to assemble these data with the fresh perspective that could come from giving our parties the same hard, cold look we so readily direct toward the parties of others; we need studies tracing the links among these variables, and assessing the relative importance of the role of parties in creating the problems we already know we have.

The question of the possible role of our parties in subverting the workings of our constitution is one of the most difficult - and therefore most interesting - to attempt to answer. It would require us to identify key elements of our constitutional system subject to subversion by party. It would motivate us to reconsider what we mean by "subversion" and whether or not 
the entirely unsubverted working of our system is really what we want: there are, after all, subversions and subversions. It would force us to remember a fact of party nature that we should keep in mind in all our studies of the role of parties within systems: parties are not single units, operated by a single will; they are boundaryless networks of actors setting up ever-changing role relationships with one another. ${ }^{13}$ This obvious but often neglected characteristic makes it dangerous to ascribe system-subverting motives to all of a party's actors even when those who have such an intent are in power. It also gives party life a far greater dynamism and unpredictability than our studies have typically suggested: recognizing this reminds us again of the importance of carrying our studies into the heart of the parties themselves, rather than accepting the inevitable distortions of party propagandists masquerading as objective respondents to our questionnaires.

\section{Conclusion: Speculations Regarding the Reasons We Have So Limited the Scope of Our Inquiries}

Why are American scholars seemingly so unwilling to give parties in their own country the same breadth of coverage they and others routinely give parties in other lands? Why do we so often (and so complacently) limit our comparative comments to a few tired clichés about the British system (with which we may or may not be acquainted), the perils of multipartyism (which we almost certainly have not verified), or the evils of democratic centralism (never distinguishing clearly between the concept and its utter distortion as practiced to date)? It is all well and good to say we have been blinded by realism and parochialism, but let us see if we can step beyond that explanation, and ask the why behind the why.

Several possible explanations come to mind. Suspecting that our parties are unlikely to stand up well in a comparative contest may itself account for our reluctance. Our failure to make clear the weakness of our parties as agencies of government and of linkage by contrasting them to more effective and/or more representative foreign models may seem to be in the best interests of the nation (although clearly not in those of the scholarly academy).

Or perhaps our problem is one of access: perhaps we fear it would be hard to go back to our sources if we dared to paint their organizations in unflattering terms, all blemishes revealed by our having asked the harder questions suggested by comparative reflection - and by our having used our own powers of observation rather than working from their inevitably distorted images of themselves.

A third possibility is that we ourselves are complicit in the underrepresentativeness of the American political system. As rather privileged 
members of what V.O. Key called the political stratum we have no obvious self-interest in changing that system by indicating the comparative weakness of our parties and explaining some of the relatively simple mechanics of other party systems that could be adapted here to strengthen their role as agencies of linkage. Indeed, self-interest appears to lie in the opposite direction.

These seem like interesting possibilities, but they all suffer from one drawback. Although it is true that the comparative method is inadequately used throughout studies of all aspects of the U.S. political system, this has not kept American scholars from doing their best, uninhibited by excessive patriotism, fear of losing access, or selfish protection of their own interests, from exposing the weaknesses of other institutions in our political system. Is there something special about political parties?

Perhaps there is. Perhaps part of our problem is that in studying political parties we have picked up their own cultural habits and we too have become excessively political, eager to please and reluctant to offend our audience. When we deal with parties as agencies of linkage, we are, after all, dealing with citizenship, and thus with one of every American's dearest image of self: member of a functioning democracy in the greatest nation on earth. As writers and teachers, we feel the cultural pressure, and we respond. We allow ourselves to become players in the game we were sent to observe. An iron quadrangle, composed of party politicians, elected politicians, politicized bureaucrats, and, now, politic scholars, all committed to telling only the most palatable parts of the truth, is formed. It surrounds the general public and closes them off from important information about parties: how their own are failing, how parties work in other lands, how those we have could be improved.

Americans who grow up in this box of mirrors, seeing only the most flattering images of themselves and their institutions reflected no matter to whom they turn, and never encouraged to look beyond these four walls, are ill-equipped to deal with the larger and more varied world in which all of us now must live. We owe them more than that.

\section{NOTES}

${ }^{1}$ For an exception, see Harmon Zeigler (1993). Uneven in style and organization, this work nevertheless treats U.S. parties in a comparative context and provides a good illustration of the kinds of important questions that force themselves to the surface when this is done. Other authors who have consistently combined the study of U.S. parties with the comparative study of other parties include Leon Epstein, Robert Harmel, Kenneth Janda, and Richard Katz. 
${ }^{2}$ Although the various definitions of party split every hair on Samson's head, nearly all contain some reference to participation in elections. For my own, see Kay Lawson (1976); for another, see Giovanni Sartori (1976).

${ }^{3}$ It follows from this line of argument that when parties are able to do a better job of fund raising and distribution than heretofore, they are well on the way to "renewal." This perspective dominates the recent work of the Committee for Party Renewal; for a rather extreme example, see Xandra Kayden and Eddie Mahe, Jr. (1985).

${ }^{4}$ Stephen E. Frantzich (1989) provides a good summary of the demands made on parties for communication resources.

${ }^{5}$ For evidence of the universality of this need, see Shaun Bowler and David M. Farrell (1992).

${ }^{6}$ The best comparative work on the interrelationship between forms of government and parties remains that of Richard Rose $(1974,1984)$.

${ }^{7}$ Harmon Zeigler (1993) provides an excellent discussion of the relationship between electoral systems and party systems in his chapter (5) on "The Institutional Structure of Choice."

${ }^{8}$ For a summary of laws impacting parties in the U.S., see Kay Lawson (1987). For that article I drew heavily on the important and largely unrecognized work of Timothy Conlan, principal author of the Advisory Commission for Intergovernmental Relation's (1986) report on The Transformation in American Politics, and of Richard Winger, publisher and editor of Ballot Access News [published at 3201 Baker Street, San Francisco, CA, 94123]. For reasons I try to make clear in the conclusion to this chapter, it is no coincidence that Winger works outside academia, as did Conlan at the time of that writing.

${ }^{9}$ This relationship is carefully explored by most of the authors contributing to Kay Lawson and Peter Merkl (1988).

${ }^{10}$ Several examples of what can be accomplished by such methods will be found in Kay Lawson (1994). It is by drawing on such work, as well as on recent developments in organizational theory, that Angelo Panebianco (1988; Italian edition, 1982) was able to develop his original and widely influential framework for the analysis of parties. (1990).

${ }^{11}$ For several studies of how these two parties stayed in power so long, see T.J. Pempel

${ }^{12}$ Two recent works of interest in this regard are Denise Baer and David Bositis (1993) and Benjamin Ginsberg and Martin Shefter (1990).

${ }^{13}$ The best work on parties as networks is by sociologist Mildred Schwartz (1990).

\section{REFERENCES}

Advisory Commission on Intergovernmental Relations. 1986. The Transformation in American Politics: Implications for Federalism. Washington, DC: U.S. Advisory Commission on Intergovernmental Relations.

Baer, Denise L. and David A. Bositis. 1993. Politics and Linkage in a Democratic Society. Englewood Cliffs, NJ: Prentice-Hall.

Bowler, Shaun and David M. Farrell. 1992. Electoral Strategies and Political Marketing. New York: St. Martin's.

Frantzich, Stephen E. 1989. Political Parties in the Technological Age. White Plains, NY: Longman. Ginsberg, Benjamin and Martin Shefter. 1990. Politics by Other Means: The Declining Importance of Elections in America. New York: Basic Books.

Kavanagh, Dennis. 1990. British Politics: Continuities and Change, 2nd ed. New York: Oxford University Press.

Kayden, Xandra and Eddie Mahe, Jr. 1985. The Party Goes On. New York: Basic Books. Lawson, Kay. 1976. The Comparative Study of Political Parties. New York: St. Martin's. 


\section{2 | Kay Lawson}

1987. How State Laws Undermine Parties. In A. James Reichley, ed., Elections American Style. Washington, DC: Brookings Institution. , ed. 1994. How Political Parties Work: Perspectives from Within. Westport, CT: Praeger.

and Peter Merkl, eds. 1988. When Parties Fail: Emerging Alternative Organizations. Princeton: Princeton University Press.

Panebianco, Angelo. 1988. Political Parties: Organization and Power. New York: Cambridge University Press.

Pempel, T.J., ed. 1990. Uncommon Democracies: The One-Party Dominant Regimes. Ithaca and London: Cornell University Press.

Riordan, William L. 1963. Plunkitt of Tammany Hall. New York: E.P. Dutton.

Rose, Richard. 1974. The Problem of Party Government. London and Basingstoke: Macmillan. 1984. Do Parties Make a Difference? Chatham, NJ: Chatham House.

Sartori, Giovanni. 1976. Parties and Party Systems: A Framework for Analysis. Cambridge: Cambridge University Press.

Schattschneider, E.E. 1942. Party Government. New York: Holt, Rinehart \& Winston.

Schlesinger, Joseph A. 1985. The New American Political Party. American Political Science Review 79: 1152-1169. Press.

1991. Political Parties and the Winning of Office. Ann Arbor: University of Michigan

Schwartz, Mildred. 1990. The Party Network: The Robust Organizing of Illinois Republicans. Madison: University of Wisconsin Press.

Zeigler, Harmon. 1993. Political Parties in Industrial Democracies. Itasca, IL: Peacock. 